\title{
Potential effects of climate change on inundation patterns in the Amazon Basin
}

\author{
F. Langerwisch ${ }^{1}$, S. Rost ${ }^{1}$, D. Gerten ${ }^{1}$, B. Poulter ${ }^{2}$, A. Rammig ${ }^{1}$, and W. Cramer ${ }^{3}$ \\ ${ }^{1}$ Earth System Analysis, Potsdam Institute for Climate Impact Research (PIK), P.O. Box 60 12 03, Telegraphenberg A62, \\ 14412 Potsdam, Germany \\ ${ }^{2}$ Laboratoire des Sciences du Climat et de l'Environnement, UMR8212, CNRS - CEA, UVSQ, Gif-sur Yvette, France \\ ${ }^{3}$ Institut Méditerranéen de Biodiversité et d'Ecologie marine et continentale (IMBE), Aix-Marseille University/CNRS, \\ Bâtiment Villemin, Europole de l'Arbois - BP 80, 13545 Aix-en-Provence cedex 04, France
}

Correspondence to: F. Langerwisch (fanny.langerwisch@pik-potsdam.de)

Received: 16 December 2011 - Published in Hydrol. Earth Syst. Sci. Discuss.: 6 January 2012

Revised: 8 March 2013 - Accepted: 1 May 2013 - Published: 20 June 2013

\begin{abstract}
Floodplain forests, namely the Várzea and Igapó, cover an area of more than $97000 \mathrm{~km}^{2}$. A key factor for their function and diversity is annual flooding. Increasing air temperature and higher precipitation variability caused by climate change are expected to shift the flooding regime during this century, and thereby impact floodplain ecosystems, their biodiversity and riverine ecosystem services. To assess the effects of climate change on the flooding regime, we use the Dynamic Global Vegetation and Hydrology Model LPJmL, enhanced by a scheme that realistically simulates monthly flooded area. Simulation results of discharge and inundation under contemporary conditions compare well against sitelevel measurements and observations. The changes of calculated inundation duration and area under climate change projections from 24 IPCC AR4 climate models differ regionally towards the end of the 21 st century. In all, $70 \%$ of the 24 climate projections agree on an increase of flooded area in about one third of the basin. Inundation duration increases dramatically by on average three months in western and around one month in eastern Amazonia. The time of high- and low-water peak shifts by up to three months. Additionally, we find a decrease in the number of extremely dry years and in the probability of the occurrence of three consecutive extremely dry years. The total number of extremely wet years does not change drastically but the probability of three consecutive extremely wet years decreases by up to $30 \%$ in the east and increases by up to $25 \%$ in the west. These changes implicate significant shifts in regional vegetation and climate, and will dramatically alter carbon and water cycles.
\end{abstract}

\section{Introduction}

Amazonia plays a vital role for the global water and carbon cycles through enormous water and carbon stores and fluxes. The Amazon catchment covers six million square kilometers and about $15 \%$ of the world's freshwater runoff is discharged by the Amazon River (Gaillardet et al., 1997). Dissolved in this water, about $33 \mathrm{Tg} \mathrm{C} \mathrm{yr}^{-1}$ are thought to be exported to the Atlantic Ocean as organic carbon (Moreira-Turcq et al.,

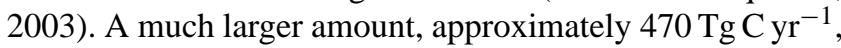
gasses out to the atmosphere as $\mathrm{CO}_{2}$ (Richey et al., 2002).

Climate and land use change currently affect Amazonian forests substantially, leading to a reduction of biomass, biodiversity and ecosystem services (Fearnside, 2004; Foley et al., 2007; Nepstad et al., 2007; Betts et al., 2008). Since the forcing from changing climate and land use appears to be nonlinearly related to the stability of the Amazonian ecosystem (Sitch et al., 2008; Nobre and De Simone Borma, 2009), this region has been identified as one of a set of global "tipping elements" particularly susceptible to global change (Lenton et al., 2008).

Much of central Amazonia is influenced by annual flooding predominantly caused by precipitation across the basin. During the flooding season between January and March (Foley et al., 2002) the water rises with an amplitude of 5 to $15 \mathrm{~m}$ (Junk, 1985) and an average speed of $0.05 \mathrm{~m} \mathrm{~d}^{-1}$ (Junk and Piedade, 1997). The extent of flooded area in central Amazonia increases from about $4 \%$ during low water to $16 \%$ during high water stage (Richey et al., 2002). The recurrent change between the terrestrial and aquatic phase forms 
characteristic and very diverse habitats for millions of plant and animal species, which are intimately related to the recurrent annual flooding. These floodplains are alternately suitable for aquatic and terrestrial organisms. The distribution of these species is especially influenced by the duration of the aquatic and terrestrial phase (Junk and Piedade, 1997). Floodplain forests cover approximately $97000 \mathrm{~km}^{2}$ (Parolin et al., 2004) and contain about $20 \%$ of the Amazonian tree species (Naiman et al., 2005). The vast floodplain areas thus represent one of the riches biota on earth, providing several ecosystem services, such as timber and fish production and carbon storage (Keddy et al., 2009).

Climate change is expected to alter temperature and precipitation patterns, which can potentially lead to changes in flood regime such as a reduction in discharge in the Amazon River (Arora and Boer, 2001). The variability in precipitation is expected to increase (Seneviratne et al., 2012) and may cause higher spatial and temporal variability in river discharge and flooded area (Coe et al., 2002). The effect of climate change on the El Niño Southern Oscillation (ENSO) remains unclear (Malhi and Wright, 2004) but ENSO changes discharge drastically (Foley et al., 2002). Changes in time, duration, and height of the flooding has the potential to shift vegetation distribution which may in turn lead to feedbacks to the atmosphere (e.g. Cox et al., 2004; Malhi et al., 2008).

To assess the effects of potential changes in precipitation and temperature on discharge and freshwater ecosystem services usually hydrological models are applied (Vigerstol and Aukema, 2011), which are, for example, WaterGAP (Alcamo et al., 2000; Döll and Zhang, 2010; Döll et al., 2003), WBM (Fekete et al., 1999), and SWAT (Arnold and Fohrer, 2005) and VIC (Liang and Xie, 2001; Liang et al., 1994). A disadvantage of these models is that they do not incorporate explicit simulation of vegetation dynamics which are an essential part of the water cycle. We use the dynamic global vegetation and hydrology model LPJmL (Bondeau et al., 2007; Gerten et al., 2004; Rost et al., 2008; Sitch et al., 2003), which has been improved for regional application to the Amazon Basin and includes the dynamic and spatially explicit reproduction of the specific hydrological patterns of the main river stem and its tributaries. These patterns consist of seasonal discharge, time and duration of low/high water periods and the changing extent of the flooded area during those periods. LPJmL combines dynamic terrestrial vegetation development with carbon and water cycles. This enables us to estimate not only the direct effect of changing precipitation and temperature on discharge but also to include the indirect effects of these changes on vegetation cover and type, which in turn alters runoff and discharge.

The main goal of our study is thus to understand and quantify the magnitude of impacts of future climate change on the Amazonian inundation patterns. We provide estimates on climate change induced shifts of inundation patterns, which comprises of time and duration of low/high water periods and the changing extent of the flooded area during those pe- riods. We describe here a method to calculate monthly inundated area. We evaluate our simulated results against observed data for discharge and potentially floodable area, and estimate changes in inundation patterns in Amazonia. To quantify the amplitude of shifts in the flooding regime due to climate change we use forcing data of the 24 General Circulation Models (GCMs) from the 4th Assessment Report of the Intergovernmental Panel on Climate Change (IPCC, 2007; Randall et al., 2007).

\section{Methods}

We apply the Dynamic Global Vegetation and Hydrology Model LPJmL (Sitch et al., 2003; Gerten et al., 2004; Bondeau et al., 2007; Rost et al., 2008) to understand and to assess the effect of climate change on current Amazonian inundation patterns. LPJmL computes establishment, abundance, vegetation dynamics, growth and productivity of the world's major plant functional types, as well as the associated carbon and water fluxes. The model is typically applied on a grid of $0.5^{\circ} \times 0.5^{\circ}$ longitude/latitude and at daily time steps. Carbon fluxes and vegetation dynamics are directly coupled to water fluxes. Modelled soil moisture, runoff and evapotranspiration were found to reproduce observed patterns well and their quality is comparable to stand-alone global hydrological models (Wagner et al., 2003; Gerten et al., 2004, 2008; Gordon et al., 2004; Biemans et al., 2009).

The river routing module of LPJmL (described by Rost et al., 2008) assumes a surface water storage pool for each grid cell representing the water storage and retention in reservoirs and lakes. The change of water storage in the river over time is represented as the runoff generated in the cell, the input of discharge accumulated from upstream grid cells, the output to the downstream cell, and the outflow of lakes in the respective cell. The output to the downstream cell is determined as a linear transport of discharge, depending on the routing velocity $(v)$ and the distance between the midpoints of the connected cells. Earlier versions of LPJmL used a globally homogeneous routing velocity of $1 \mathrm{~ms}^{-1}$ (Rost et al., 2008), which had difficulties to reproduce the Amazonian hydrograph, with shifts within the hydrograph of several months. In a former study we already improved the reproduction of the hydrograph by applying a homogeneously reduced routing velocity of $0.25 \mathrm{~ms}^{-1}$ to the Amazon Basin leading to substantial reductions of the shift for several observation sites (Langerwisch et al., 2008). Our new approach is to use heterogeneous routing velocities which take topographic differences within the Amazon catchment into account for further improvement of the hydrograph. 
Table 1. Slope classes.

\begin{tabular}{lc}
\hline Slope range & Class \\
\hline$\leq 1.5^{\circ}$ & 5 \\
$>1.5-\leq 3^{\circ}$ & 4 \\
$>3-\leq 6^{\circ}$ & 3 \\
$>6-\leq 10^{\circ}$ & 2 \\
$>10-\leq 35^{\circ}$ & 1 \\
$>35^{\circ}$ & 0 \\
\hline
\end{tabular}

Table 2. Relative slope position classes.

\begin{tabular}{lc}
\hline Distance range & Class \\
\hline $0-10$ cells & 22 \\
$11-20$ cells & 19 \\
$21-40$ cells & 13 \\
$41-60$ cells & 12 \\
$61-80$ cells & 11 \\
$>81$ cells & 10 \\
\hline
\end{tabular}

\subsection{Calculation of routing velocity and potential floodable area}

We extend on earlier work (Langerwisch et al., 2008) and take topography into account by calculating cell specific routing velocities, which are comparable to river flow velocities. In the model, the routing velocity is used to calculate the distance that runoff water can move within a time step (see also Rost et al., 2008). We also estimate the extent of potential floodable area and monthly flooded area.

We use a digital elevation model (DEM) provided by the WWF database HydroSHEDS (WWF HydroSHEDS, 2007) at a resolution of 15 arc seconds longitude/latitude, corresponding to approximately $460 \mathrm{~m}$ edge length in the study region, to calculate the routing velocity and the floodable area. We apply grid-based elevation data (instead of elevation data of the actual gauging stations) to obtain a continuous spatially consistent basis for our calculations. The DEM elevation represents the top of the canopy, which is $\sim 30 \mathrm{~m}$ lower than the actual ground elevation (Anderson et al., 2009). For the Amazon Basin, we assume this to be a systematic error in the DEM elevation and use it directly for calculating the routing velocity. The calculations of the routing velocity were conducted applying well-established techniques (for details see Supplement S1 and S2). The data were processed at the original resolution of HydroSHEDS. Final results are re-sampled at $0.5^{\circ} \times 0.5^{\circ}$ (longitude/latitude) resolution.

\subsubsection{Routing velocity}

Based on the DEM we calculate the cell's slope and the corresponding routing velocity (details see Supplement S1 and $\mathrm{S} 2$ ). The calculation of the high resolution slope $S$ [degree] is
Table 3. Landform types with corresponding slope and mTRMI.

\begin{tabular}{lrr}
\hline Landform type & Slope range & mTRMI \\
\hline valley flats & $<3^{\circ}$ & $>22$ \\
nearly level terraces & $<3^{\circ}$ & $\leq 22$ \\
gently sloping toe slopes, and bottoms & $\geq 3-<10^{\circ}$ & $>18$ \\
gently sloping ridges & $\geq 3-<10^{\circ}$ & $\leq 18$ \\
very moist steep slopes & $\geq 10-\leq 35^{\circ}$ & $\geq 18$ \\
moderately moist steep slopes & $\geq 10-\leq 35^{\circ}$ & $11-17$ \\
dry steep slopes & $\geq 10-\leq 35^{\circ}$ & $<10$ \\
\hline
\end{tabular}

based on the work of Burrough (1986). We apply the median of all subcell values to aggregate the high resolution slope to a $0.5 \times 0.5^{\circ}$ cell slope. Subsequently, we calculate slope dependent routing velocity $v\left[\mathrm{~ms}^{-1}\right]$ (Eq. 1, Fig. S1) based on the Manning-Strickler formulation:

$v=\left(\tan \left(S \times \frac{\pi}{180}\right)\right)^{\frac{1}{2}} \times k \times R^{\frac{2}{3}}$,

where $k$ is the Manning-Strickler coefficient $\left[\mathrm{m}^{1 / 3} \mathrm{~s}^{-1}\right]$ describing the roughness of the area. For natural rivers this value ranges between 28 and $40 \mathrm{~m}^{1 / 3} \mathrm{~s}^{-1}$ (Patt, 2001). Due to the lack of detailed cell specific information we set $k=$ $35 \mathrm{~m}^{1 / 3} \mathrm{~s}^{-1} . R$ is the hydraulic radius [m]. It describes the ratio between the cross-sectional area $\left[\mathrm{m}^{2}\right]$ and the wetted perimeter $[\mathrm{m}]$ of the channel. In wide and shallow waters it corresponds to the depth of the water. It is higher in narrow and deep river sections and lower in wide shallow river sections, but cell specific information for $R$ are not available, therefore we neglect the influence of this factor and set $R=1.0 \mathrm{~m}$. The median of the calculated routing velocity is $0.25 \mathrm{~ms}^{-1}$. We included an analysis to estimate the sensitivity of the calculated routing velocity to $k$ and $R$. We varied $k$ between 28 and $40 \mathrm{~m}^{1 / 3} \mathrm{~s}^{-1}$ (with a constant $R=1.0 \mathrm{~m}$ ), which lead to median routing velocities between $0.20 \mathrm{~ms}^{-1}$ $(-20.0 \%)$ and $0.29 \mathrm{~ms}^{-1}(+16 \%)$. We varied $R$ between 0.2 and $1.2 \mathrm{~m}$ (with a constant $k=35 \mathrm{~m}^{1 / 3} \mathrm{~s}^{-1}$ ), which lead to median routing velocities between $0.09 \mathrm{~ms}^{-1}(-64 \%)$ and $0.29 \mathrm{~ms}^{-1}(+169 \%)$. Additionally, we tested all possible $k$ and $R$ combinations in the range given above (see Fig. S2).

\subsubsection{Floodable area}

As a basis for the calculation of inundation, we first estimate the potentially floodable area by applying the same DEM used for the routing velocity calculation (see Sect. 2.1.1). We determine a modified Topographic Relative Moisture Index (mTRMI) based on the work of Parker (1982) on the native resolution of the DEM (15 arc seconds). This index is applied to classify structural landscape conditions which can be arranged in 7 different landform types, such as valley flats and dry steep slopes (also see Tables 1-3). It uses several weighted geomorphologic characteristics such as slope, slope steepness, slope configuration, relative slope position, 
Table 4. List of the 24 IPCC coupled general circulation models (GCMs) used in this study. Details for the climate models see IPCC 2007 AR4, chapter 8 (Randall et al., 2007).

\begin{tabular}{ll}
\hline Model name & \\
\hline BCCR - BCM 2.0 & INGV - SXG \\
CCCMA - CGCM 3.1 (T47) & INM - CM 3.0 \\
CCCMA - CGCM 3.1 (T63) & IPSL - CM 4 \\
CNRM - CM 3 & MIROC 3.2 (hires) \\
CSIRO - Mk 3.0 & MIROC 3.2 (medres) \\
CSIRO - Mk 3.5 & MIUB - ECHO-G \\
GFDL - CM 2.0 & MPI - ECHAM 5 \\
GFDL - CM 2.1 & MRI - CGCM 2.3.2 \\
GISS - AOM & NCAR - CCSM 3 \\
GISS - EH & NCAR - PCM 1 \\
GISS - ER & UKMO - HadCM 3 \\
FGOALS - g 1.0 & UKMO - HadGEM 1 \\
\hline
\end{tabular}

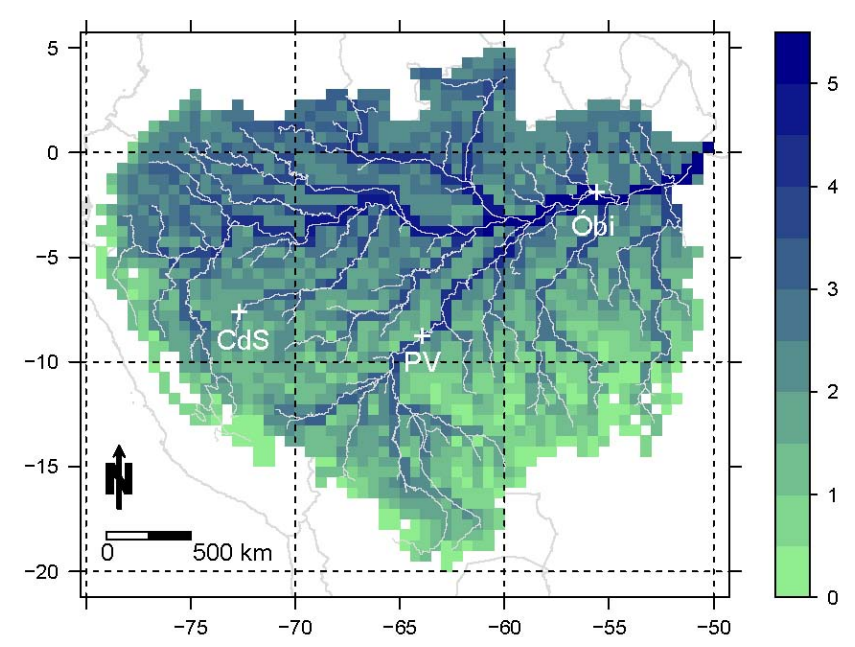

Fig. 1. Simulated mean discharge $\left[\log \mathrm{m}^{3} \mathrm{~s}^{-1}\right]$ during June, averaged over the reference period 1961-1990. The white crosses indicate the exaple sites Cruzeiro do Sul (CdS, ID 3), Porto Velho (PV, ID 41), and Óbidos (Óbi, ID 10 and 42).

and aspect which can be calculated from the DEM. We use the resulting landform type valley flats as potentially floodable area.

In our study, mTRMI is the sum of classified slope, classified slope configuration and classified relative slope position (Eq. 2, see below for definitions).

$$
\text { mTRMI }=S_{\text {class }}+S_{\text {config }_{\text {class }}}+S_{\text {pos }_{\text {class }}}
$$

We neglect aspect because differences between north and south facing slopes are insignificant in the tropics (compare to Donnegan et al., 2007). A detailed description of the calculation of mTRMI summands can be found in the Supplement.

The first summand is classified slope (Eq. 2, $S_{\text {class }}$ ). We use the previously calculated slope values and slice them in six slope classes (Table 1).

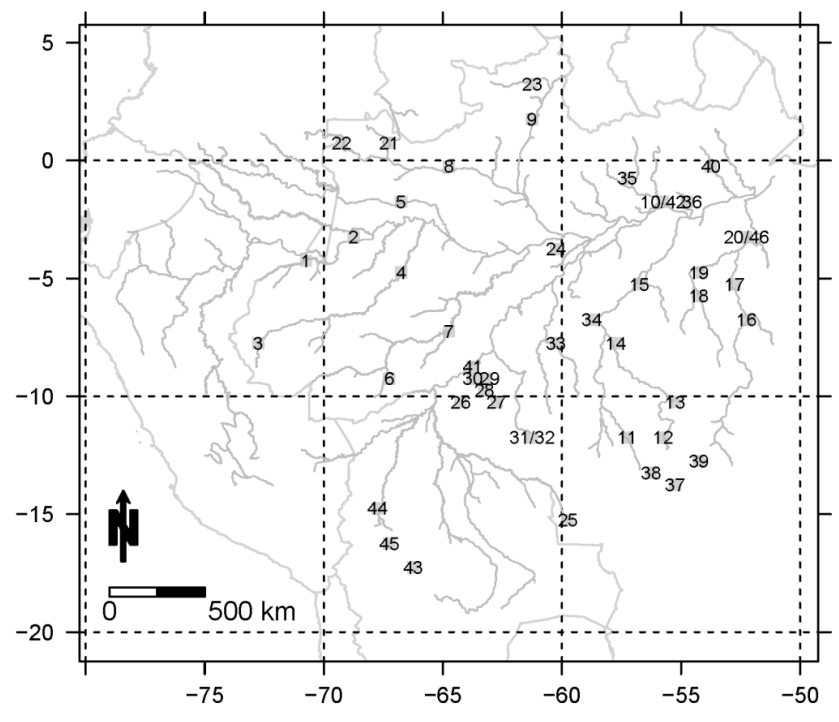

Fig. 2. The 44 sites used for comparison of observed and simulated discharge.

The second summand is classified slope configuration (Eq. 2, $S_{\text {conf }}$ class $)$. Slope configuration describes the convexity or concavity of the land surrounding any grid cell, based on the change in elevation $Z[\mathrm{~m}]$ from cell $_{i, j}$ to all cells located at the edge of the $5 \times 5$ cell window. We slice the full range of resulting values equally into 10 parts and assign these parts into 3 slope configuration classes: slices $0-4$ to class -1 (convex topography); slice 5 to class 0 (flat topography); slices 6-10 to class 1 (concave topography).

The third summand is relative slope position (Eq. 2, $S_{\text {pos }_{\text {class }}}$ ) describing the distance of the $\operatorname{cell}_{i, j}$ to the closest ridges and streams. We assign the distance [cells] to 6 relative slope position classes (Table 2).

From the slope classes (Eqs. S1-S3), the slope configuration classes (Eqs. S5-S9) and the relative slope position classes (Eqs. S10-S11) we calculate mTRMI (Eq. 2). We sum up classified slope (0 to 5), classified slope configuration ( -1 to 1$)$, and classified relative slope position (10 to 22). The mTRMI ranges from dry to wet (9 to 28), describing site conditions.

We generate a map (15 arc seconds resolution) of landform types by combining slope $S$ and mTRMI. For this purpose we group sites with defined mTRMI and slope to certain landform types (details in Table 3). Finally, we use the landform type valley flat, which is potentially floodable area, to calculate the fraction [\%] of floodable area for each $0.5 \times 0.5^{\circ}$ grid cell.

We then calculate the fraction of continuously flooded area from the potentially floodable area (per $0.5 \times 0.5^{\circ}$ cell) from the work of Richey et al. (2002). They estimated that during low water stage about $4 \%$, and during high water stage about $16 \%$ of a 1.77 million $\mathrm{km}^{2}$ quadrant of the central Amazon Basin is covered with water. This means that $25 \%$ of 


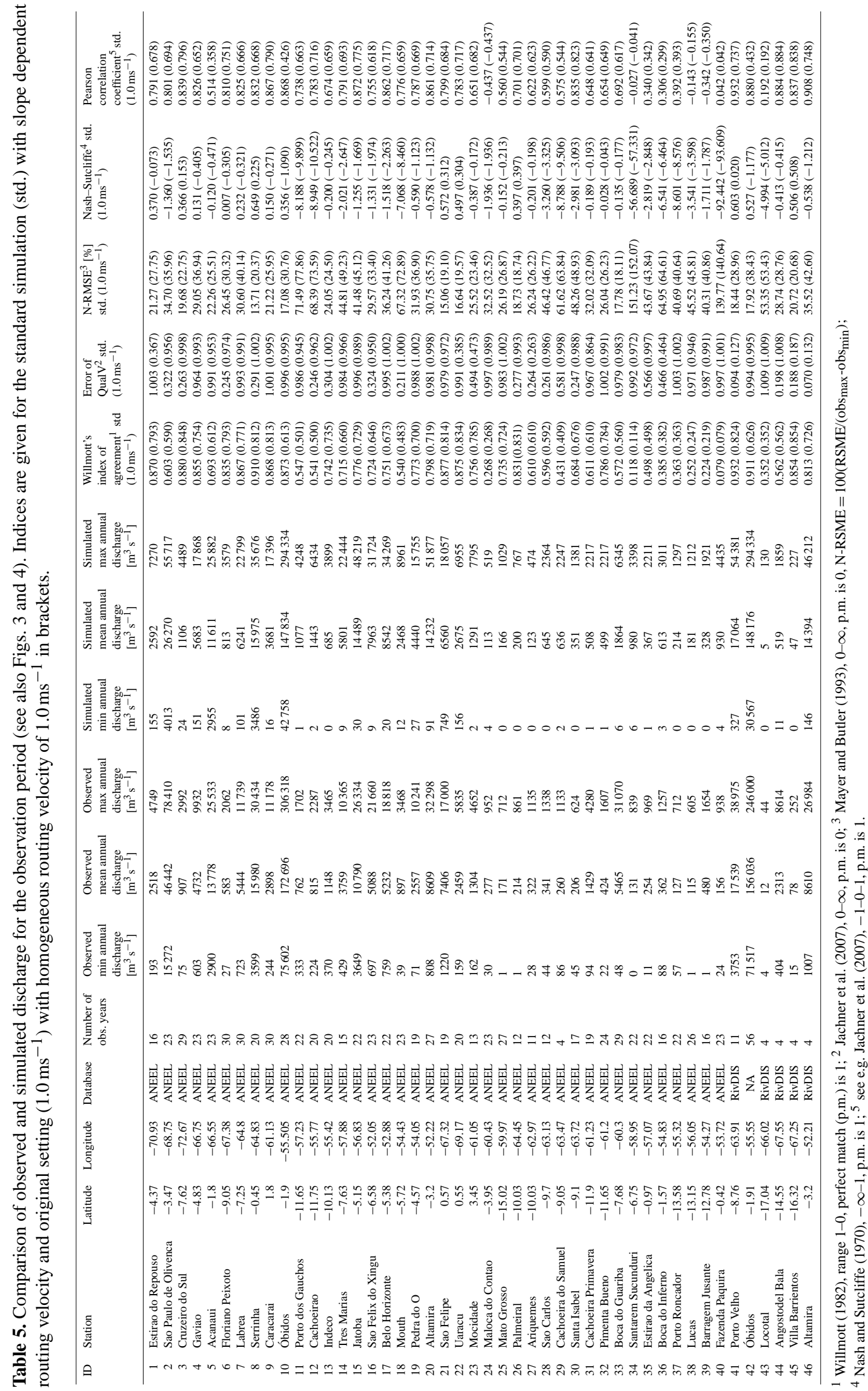



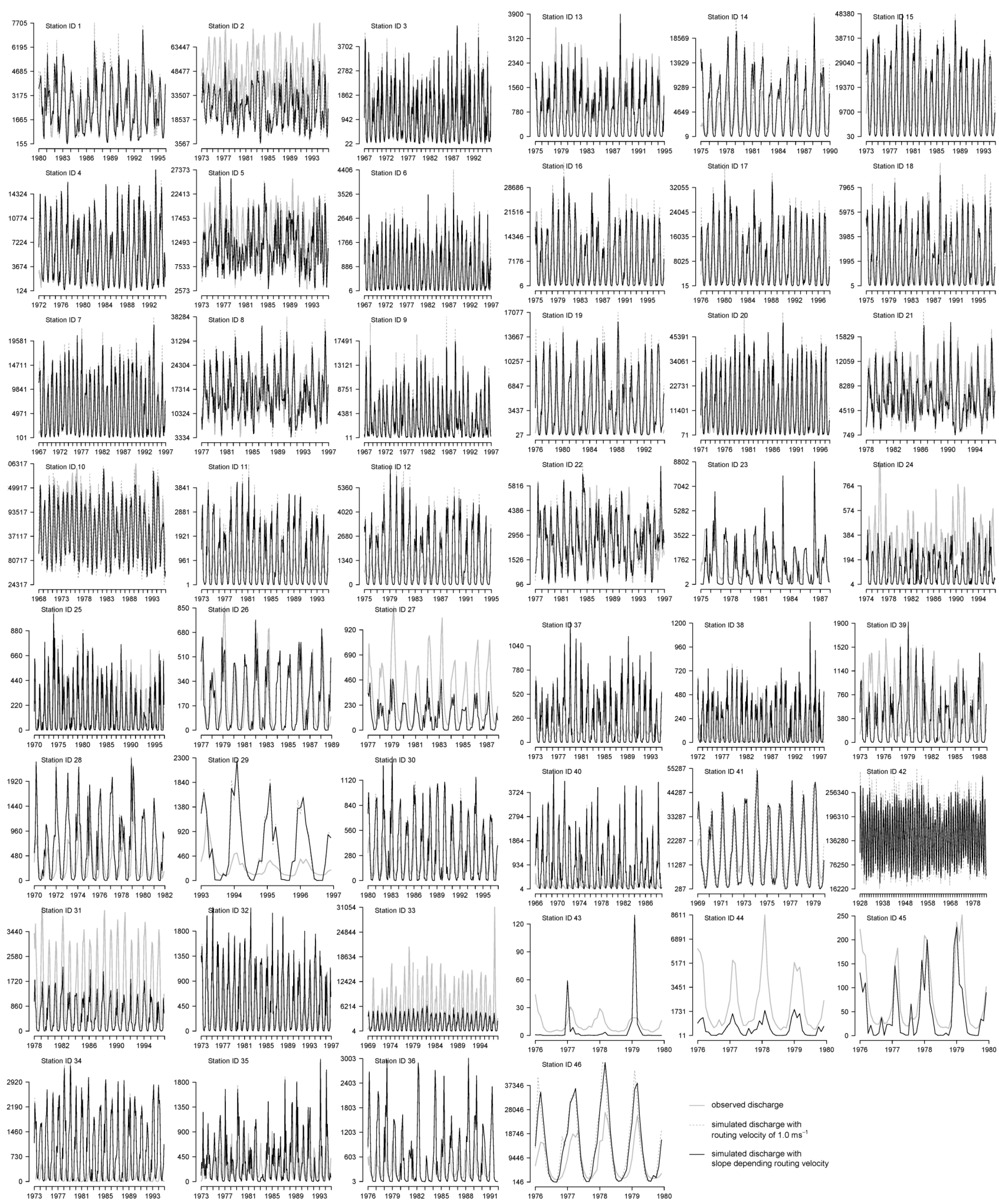

Fig. 3. Observed and simulated discharge $\left[\mathrm{m}^{3} \mathrm{~s}^{-1}\right]$ for all 44 sites. Observed discharge as solid grey line, simulated discharge with routing velocity of $1.0 \mathrm{~ms}^{-1}$ as dashed grey line, and simulated discharge with slope depending routing velocity as solid black line. 
Table 6. Comparison of observed floodplain area and calculated floodable area in the subregions of the basin. R denotes the rectangle number in Fig. 5.

\begin{tabular}{|c|c|c|c|c|c|c|c|}
\hline \multirow{3}{*}{ Source } & \multirow{3}{*}{$\mathrm{R}$} & \multirow{3}{*}{ North-west corner } & \multirow{3}{*}{ South-east corner } & \multicolumn{4}{|c|}{ Floodplain } \\
\hline & & & & \multicolumn{2}{|c|}{ area $\left[10^{3} \mathrm{~km}^{2}\right]$} & \multicolumn{2}{|c|}{ fraction [\%] } \\
\hline & & & & published & calculated & published & calculated \\
\hline Richey et al. (2002) & 1 & $0^{\circ} / 72^{\circ} \mathrm{W}$ & $8^{\circ} \mathrm{S} / 54^{\circ} \mathrm{W}$ & 290.0 & 239.5 & 16.3 & 13.5 \\
\hline Melack et al. (2004) & 1 & $0^{\circ} / 72^{\circ} \mathrm{W}$ & $8^{\circ} \mathrm{S} / 54^{\circ} \mathrm{W}$ & 190.3 & 239.5 & 10.7 & 13.5 \\
\hline Hess et al. (2003) & 1 & $0^{\circ} / 72^{\circ} \mathrm{W}$ & $8^{\circ} \mathrm{S} / 54^{\circ} \mathrm{W}$ & 303.0 & 239.5 & 17.0 & 13.5 \\
\hline Hamilton et al. (2002) & 2 & $2^{\circ} \mathrm{S} / 70^{\circ} \mathrm{W}$ & $5^{\circ} \mathrm{S} / 52^{\circ} \mathrm{W}$ & 97.4 & 91.4 & 14.6 & 13.7 \\
\hline Hamilton et al. (2002) & 3 & $12^{\circ} \mathrm{S} / 68^{\circ} \mathrm{W}$ & $16^{\circ} \mathrm{S} / 61^{\circ} \mathrm{W}$ & 92.1 & 49.4 & 27.4 & 14.7 \\
\hline
\end{tabular}

the high water flooded area is also covered during low water. We therefore assume that $25 \%$ of the potential floodable area is continuously covered with water.

Estimations of the inundation with models and/or remote sensing has, besides Richey et al. (2002), already conducted, for example, by Alsdorf et al. (2007, 2010) and Bates and De Roo (2000). A comparison of remotely sensed inundation and modelled inundation has been conducted by Wilson et al. (2007) and Bates (2012). These studies also discuss the applicability of modeling and remote sensing to the inundation estimation. Due to the high spatial and temporal variability in large catchments these methods are excellent tools to investigate inundation patterns.

The actual monthly flooded area is calculated by assuming that under current conditions (reference period 19611990) the floodable area is totally covered with water if the reference mean of the maximal monthly discharge per year (i.e. high water stage) plus the standard deviation for this period is reached. Therefore, it is possible that more than the maximal floodable area is flooded during anomalously high water discharge years.

\subsection{Data and simulations}

LPJmL is run in its natural vegetation mode at $0.5 \times 0.5^{\circ} \mathrm{spa}-$ tial resolution for the period 1901-2099. Transient runs are preceded by $1000 \mathrm{yr}$ spin up during which the pre-industrial $\mathrm{CO}_{2}$ level of $280 \mathrm{ppm}$ and the climate of the years 1901-1930 are repeated to obtain equilibrium for vegetation, carbon and water pools.

For the model evaluation we perform model runs using climate forcing data from a homogenized and extended CRU TS2.1 global climate dataset covering the years 1901 to 2003 (Österle et al., 2003; Mitchell and Jones, 2005). For the projections we take climate forcing data from 24 coupled general circulation models (GCMs, Table 4) chosen for the 4th Assessment Report of the IPCC (Nakićenović et al., 2000; Meehl et al., 2007) calculated under the SRES A1B scenario. Since all current climate models show considerable biases for the Amazon Basin, we apply an anomaly approach (Rammig et al., 2010). The anomaly approach determines the climate model bias for the reference period (1961-1990) as the difference (for temperature) or the ratio (for precipitation and cloud cover) of the $30 \mathrm{yr}$ means of climate model output (24 climate projections from IPCC-AR4) and observed climate (CRU) for each month and each grid cell. With this approach climate model bias is removed and the climate input for LPJmL is standardized (Rammig et al., 2010).

To get quasi-daily values, the monthly values of temperature and cloud cover are linearly interpolated. Daily precipitation amount and distribution of wet days to calculate core processes such as photosynthesis, water fluxes and vegetation growth, are inferred using a stochastic method (Gerten et al., 2004). This method of using monthly inputs and recalculate them to quasi-daily values is used in most large-scale multiple-scenario studies (Alcamo et al., 2003; Biemans et al., 2011; Rost et al., 2008). Whether the treatment of climate data, with the present implementation of the weather generator in our model, significantly affects simulating results relative to the climate change signal is being investigated in an on-going study (Gerten et al., 2012). Soil information is derived from the FAO global database (FAO, 1991; Sitch et al., 2003).

\subsection{Model evaluation and projections}

\subsubsection{Current conditions}

We compare observed monthly discharge from the "River Discharge Database" of the "Center for Sustainability and the Global Environment" (2007) with simulated monthly discharge at 44 sites for corresponding time periods. Additionally, to the simulation with the improved slope dependent routing velocity, we also compare the simulated discharge calculated with the original LPJmL routing velocity of $1.0 \mathrm{~ms}^{-2}$. This shows the improvement of the introduction of the slope dependent routing velocity. The observed and simulated discharge for the 44 observation sites (Fig. 2) are shown in Fig. 3 (details in Table 5). We evaluate the quality of our model simulations with the Willmott's index of agreement, which ranges from 0 to 1 , with 1 indicating complete agreement (Willmott, 1982) and the error of the qualitative 

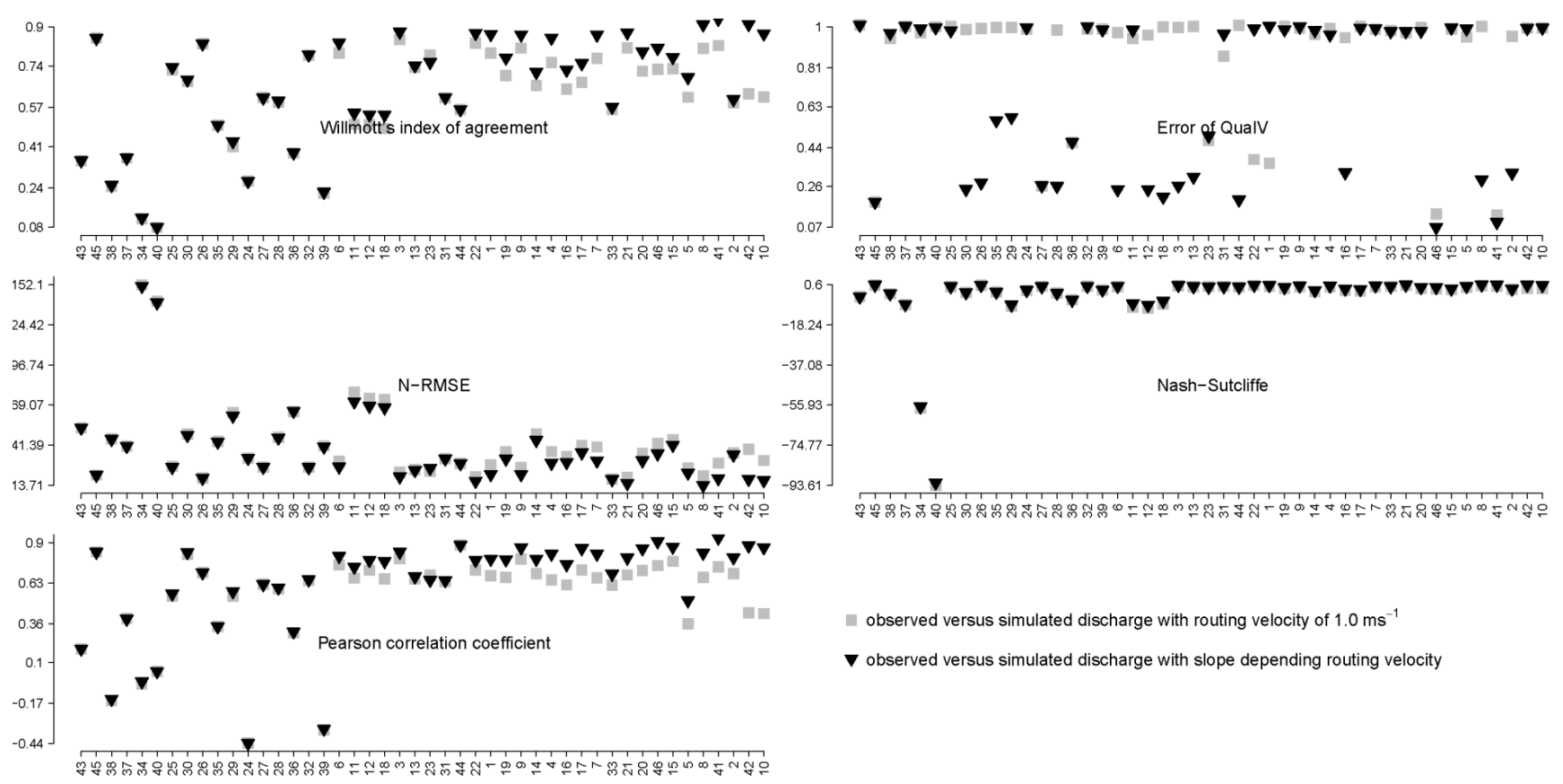

- observed versus simulated discharge with routing velocity of $1.0 \mathrm{~ms}^{-1}$

$\nabla$ observed versus simulated discharge with slope depending routing velocity

Fig. 4. Comparison of observed and simulated discharge for all 44 observation sites with 5 indices (details in Table 5). Sites are sorted according the observed mean annual discharge $\left[\mathrm{m}^{3} \mathrm{~s}^{-1}\right]$, with the lowest discharge site at the left hand site.

validation (QualV), which ranges from 0 to infinite, with low values indicating high agreement (Jachner et al., 2007). We also calculate the normalised RMSE, Nash-Sutcliffe coefficient and Pearson correlation coefficient (Mayer and Butler, 1993; Nash and Sutcliffe, 1970). A summary of these results is given in Table 5 and Fig. 4.

For further evaluation, we compare the calculated floodable area with published values of floodplain area for 3 subregions of the basin (Hamilton et al., 2002; Richey et al., 2002; Melack et al., 2004; Lehner and Döll, 2004; details in Table 6 and Fig. 5).

\subsubsection{Projections}

Future changes in inundated area, duration of inundation, and high and low water peak month are evaluated by comparing the years 1961 to 1990 (reference period) with data from the last 30 model years 2070 to 2099 (future period). We extend our analysis to identify changes in frequency of extreme events (i.e. droughts and very high floods). In this context, we define "extreme flood" as the flooded area being larger than the $30 \mathrm{yr}$ median flooded area added by the standard deviation (for the considered time period). We define "extreme drought" as the flooded area being smaller than the mean flooded area reduced by the standard deviation. We calculate proportion of models in agreement in certain events by combining results of the 24 different model runs. If all model runs $(24 / 24)$ show this event the proportion is $100 \%$, and $4 \%$ if only one model run shows this event.

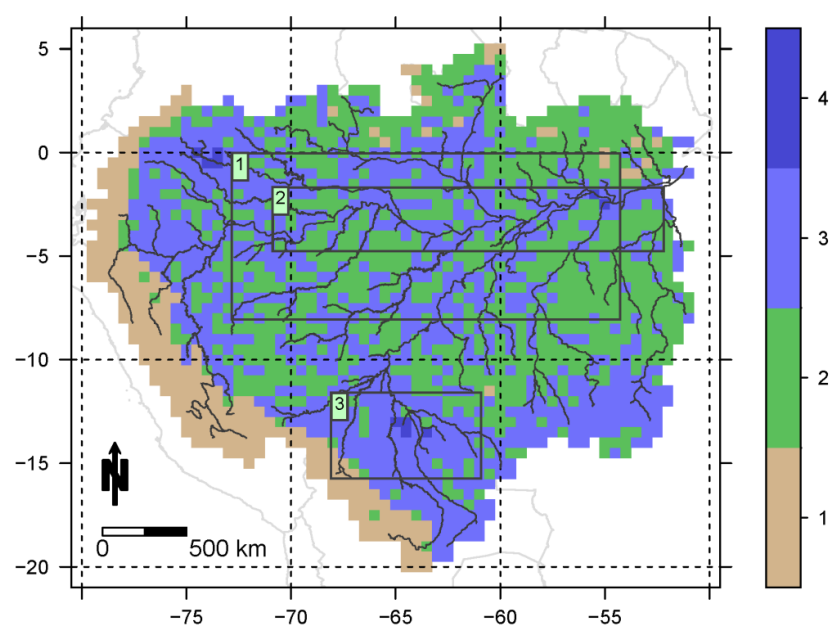

Fig. 5. Fraction classes of floodable area per cell. Class 1 representing $<5 \%$, class 2 representing $\geq 5-10 \%$, class 3 representing $\geq 10-15 \%$, class 4 representing $\geq 15-45 \%$ of floodable area. For a comparison of simulated floodable area with floodplain area (rectangles R1-R3) see Table 6. 

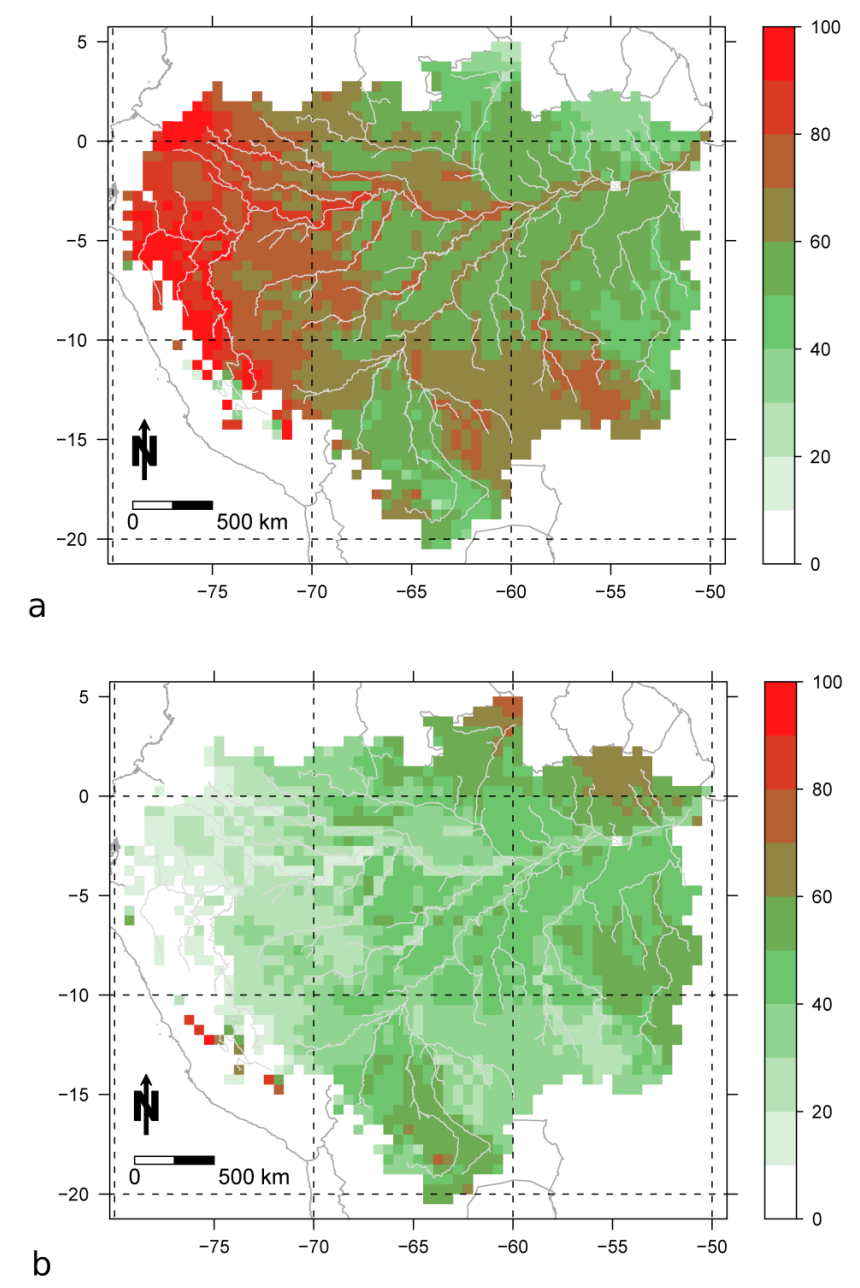

Fig. 6. Proportion of models in agreement [\%] in (a) an increase and (b) a decrease of mean annual inundated area per cell. The proportion represents the agreement between the 24 model runs showing an increase or a decrease in inundated area, respectively.

\section{Results and discussion}

\subsection{Current conditions}

\subsubsection{Routing velocity}

The calculated routing velocity is highest in the Andean region, where the slopes are steepest, and lowest in the depression of the basin (Fig. S1). Both the Guiana Highlands and the Brazilian Highlands (north-west and south of the mouth, respectively) can be identified with a slightly higher velocity than the lowland. For the three example sites Cruzeiro do Sul, Porto Velho and Óbidos, we calculate routing velocities of $0.25 \mathrm{~ms}^{-1}$, which agree with those reported by Birkett et al. (2002) and Richey et al. (1989) who measured a flow velocity of $0.35 \pm 0.05$ and $0.3 \mathrm{~ms}^{-1}$, respectively. A sensitivity analysis carried out to estimate the effect of altered $R$ and $k$ values (Eq. 1) on the routing velocity showed that the

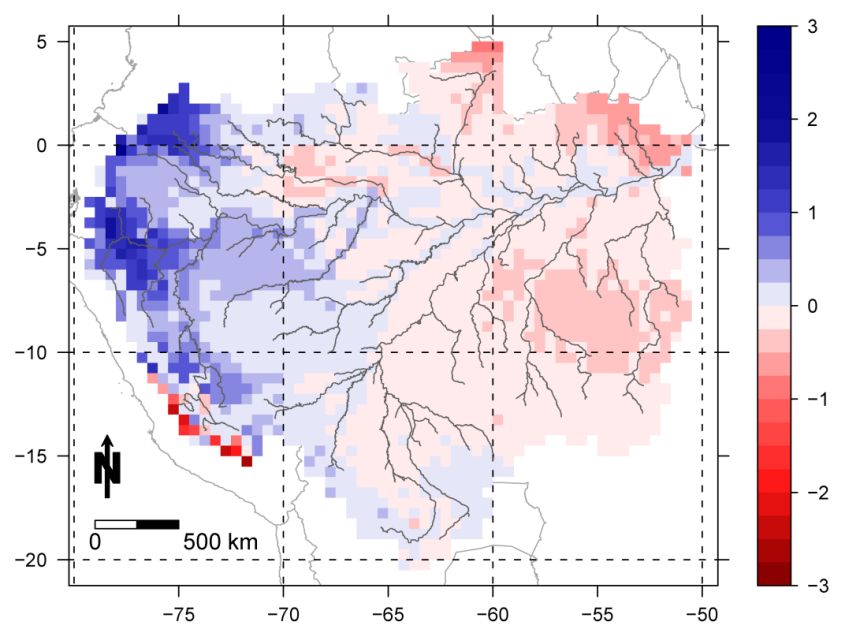

Fig. 7. Lengthening (blue) and shortening (red) of duration of inundation in months (mean over 24 model realisations) between future and reference period.

calculated velocities are less sensitive to changes in $k$ than in $R$ (for details see Fig. S2). Depending on $k$ and $R$, the calculated basin wide mean velocity ranges between 0.07 and $0.33 \mathrm{~ms}^{-1}$, while the applied velocity is $0.25 \mathrm{~ms}^{-1}$.

Our model input velocities are calculated using slope medians over $0.5 \times 0.5^{\circ}$ cells and thereby steep and plane areas are combined, which leads to differences between simulated routing velocities and the observed flow velocities. We are aware that our approach of applying the standard ManningStrickler formulation to such large spatial scales is limited and that information on the parameterisation is missing. We attribute the uncertainty of the parameters by conducting an analysis to estimate the sensitivity of the routing velocity to $k$ and $R$ (see Supplement S1). This in combination with the effective reproduction of observed hydrographs (details in Table 5) confirms that our method is suitable for our simulation purposes.

\subsubsection{Simulated discharge}

For most of the sites the characteristics of the simulated hydrograph, such as time and height of high and low water phase agree with observed hydrographs (Fig. 3, Table 5). Due to scaling effects the model underestimates, however, the discharge at several sites (Fig. 3). These scaling effects may in part be caused by the averaging out of the high discharge in cells that do not fully cover the measured river reach as well as the false estimation of sites which belong to the same simulated cell. This problem could be overcome by applying the model on a smaller scale or by including a larger amount of measurement data, if available, to better represent the average discharge of the certain area.

In our further analysis of shifts of high and low water peak months due to climate change, we compare the simulated peak month during a reference period with simulated peak 

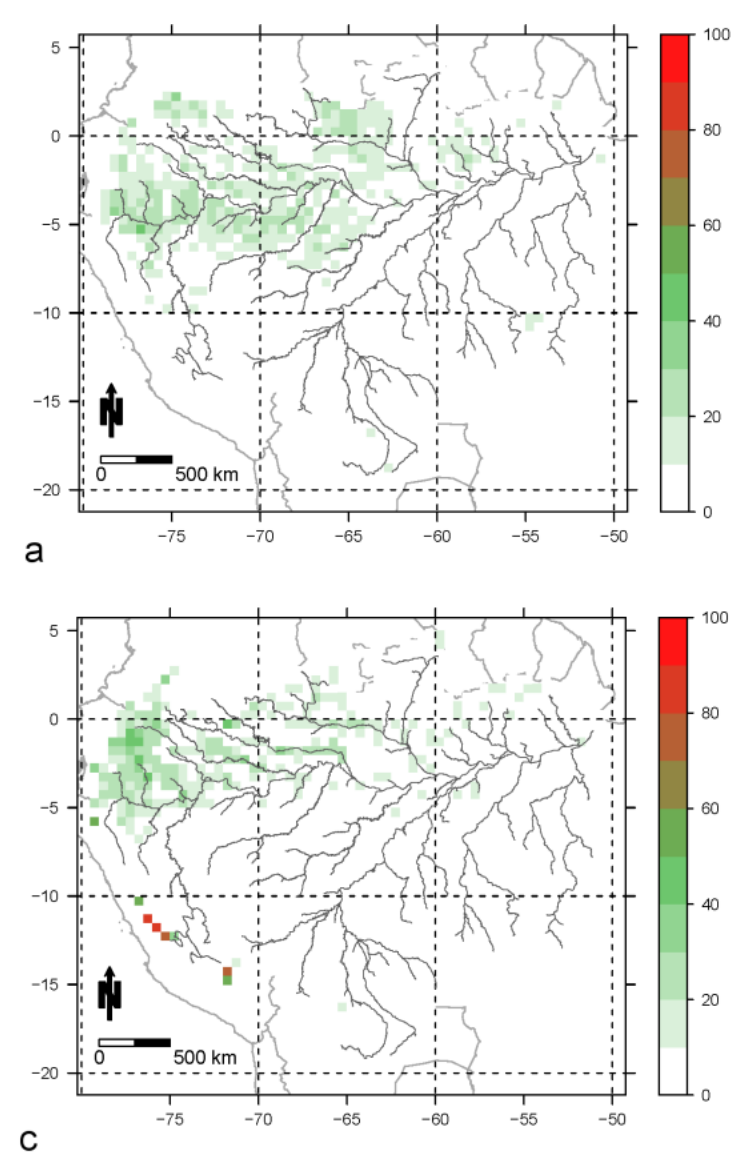
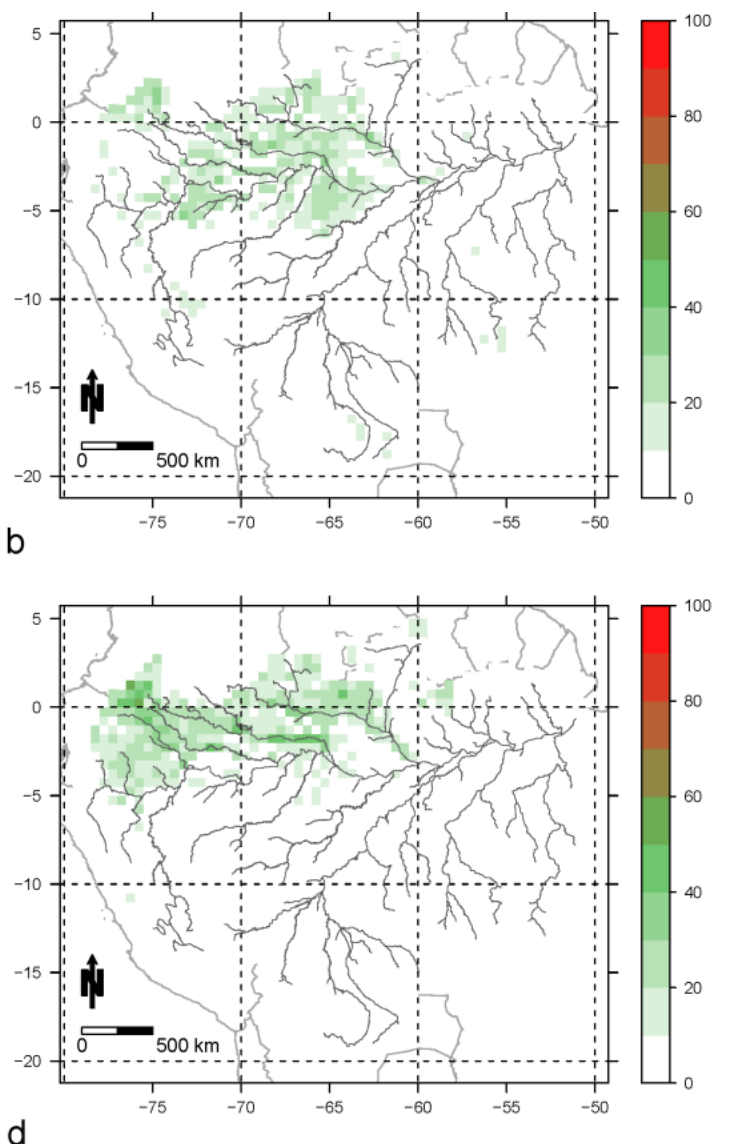

Fig. 8. Proportion of models in agreement [\%] in a forward shift $(\mathbf{a}, \mathbf{c})$ and backward shift $(\mathbf{b}, \mathbf{d})$ between future and reference period of at least 3-months of high water peak month $(\mathbf{a}, \mathbf{b})$ and low water peak month $(\mathbf{c}, \mathbf{d})$.

months during a future period. We are therefore confident that the small deviations to earlier peak month in the model will not affect the calculated differences between reference and future period.

In our work we simulate the discharge for sites with less than $10 \mathrm{~m}^{3} \mathrm{~s}^{-1}$ as well as sites with more than $100000 \mathrm{~m}^{3} \mathrm{~s}^{-1}$ mean June discharge (see Fig. 1). Concerning this wide range of discharge within the basin, the reproduction of the overall discharge pattern is unprecedented for a model with predictive capacity. We reproduce the order of magnitude of discharge and regarding the standard deviation of the observed discharge, we see that our model results can reproduce the discharge in low, medium and high discharge sites.

For the comparison of observed and simulated discharge, for all 44 gauging stations, we calculated Willmott's index of agreement, error of qualitative validation, normalised RMSE, Nash-Sutcliffe coefficient, and the Pearson correlation coefficient. The wide range of indices offers the possibility to compare the discharge data under different aspects. Four out of the five indices show for most of the sites a high agreement between simulated and observed discharge. The Willmott's index of agreement is in 23 of the 44 sites (52\%) larger than 0.7 , compare to 18 sites $(41 \%)$ simulated with the original homogenous routing velocity of $1.0 \mathrm{~ms}^{-1}$ (Table 5). The error of the QualV is in 18 sites ( $41 \%$ ) smaller than 0.5, compared to 8 sites $(18 \%)$. For the three example sites Cruzeiro do Sul, Porto Velho, and Óbidos the Willmott's index of agreement is $0.88,0.93$, and 0.91 , respectively. The error of QualV for these sites is $0.26,0.09$, and 0.99 , respectively. It has to be taken into account that for this analysis the model was run in its natural vegetation mode. It is known that deforestation changes the hydrological flows, e.g. due to changes in surface runoff (Foley et al., 2007). This might lead to small differences between observed and simulated discharge.

\subsubsection{Floodplain area}

A comparison of floodplain area in three part of the basin shows that calculated floodable area agrees with published values for floodplain area. Cells with a high fraction of floodable area are concentrated along the main stems of the river network (Fig. 5). In addition to the Amazon main stem, a large potentially floodable area is calculated in the south of the region (around $15^{\circ} \mathrm{S}, 65^{\circ} \mathrm{W}$ ), realistically reproducing 

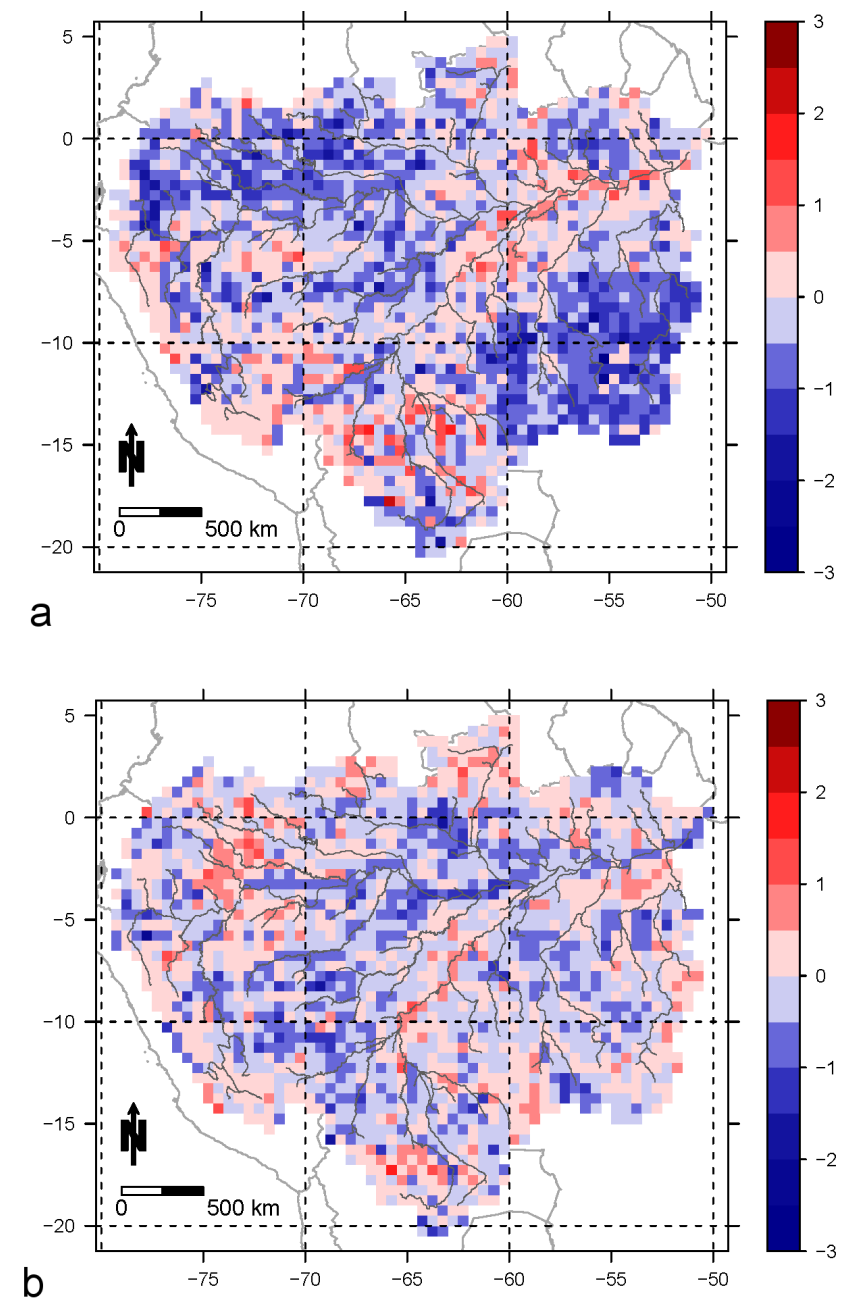

Fig. 9. Difference of the number of (a) extremely dry years and (b) extremely wet years between future and reference period.

the Llanos de Moxos wetland (upper Rio Madeira basin). This vast area of about $150000 \mathrm{~km}^{2}$ is inundated annually for 3 to 4 months (Hamilton et al., 2002). According to Melack et al. (2004) about $14 \%$ of the whole Amazon Basin is floodable, this agrees with our result of $12.6 \%$. Detailed comparison with published data for 3 subregions of the basin (rectangles R1-R3 in Fig. 5) with Hamilton et al. (2002), Richey et al. (2002), Hess et al. (2003) and Melack et al. (2004) shows that calculated and observed values are in comparable range for 3 of the 4 regions (Fig. 5, Table 6). In the central basin (R1 and R2 in Fig. 5) our values of floodable area are close to observed values. For R1 the value is in between reported values. We underestimate by $17.4 \%$ compared to Richey et al. (2002) and by $21 \%$ compared to Hess et al. (2003), and we overestimate by $26 \%$ compared to Melack et al. (2004). For R2, also situated in central Amazonia we underestimated by $6 \%$ in comparison to Hamilton et al. (2002). Bigger differences were found for the Llanos de Moxos (R3). Here we underestimated the floodable area by about $46 \%$ compared to
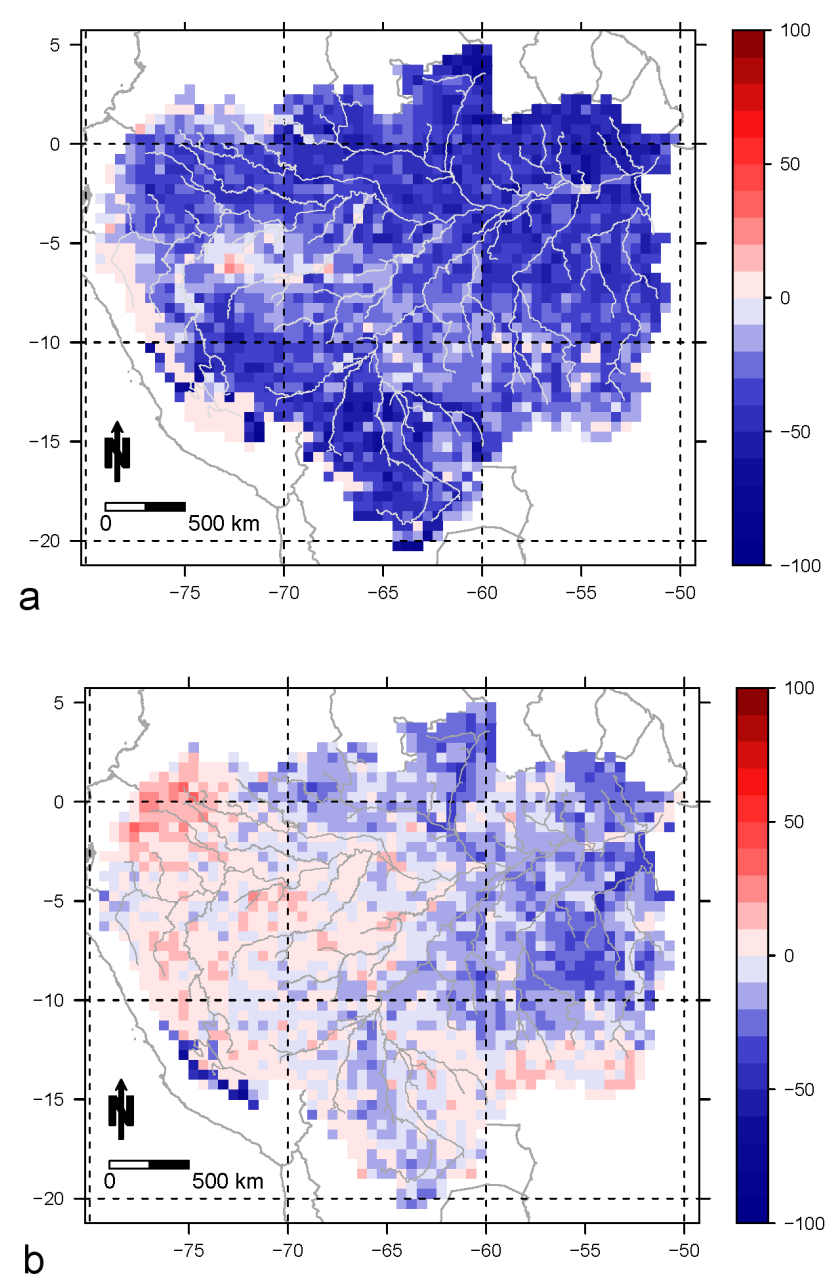

Fig. 10. Difference in the probability of at least three consecutive extremely dry years (a) and extremely wet years (b) between the future and reference period.

Hamilton et al. (2002). However, he and his colleagues examine only the Llanos de Moxos, while our rectangular region also includes parts outside this area. Thus, our underestimation of the floodable area in this region is probably a result of the comparison of two slightly different spatial subsets.

The connectivity between floodplain and river depends on small-scale characteristics, such as small channels. We approximate this connectivity on a large-scale of $0.5^{\circ}$ by building our analysis on a high resolution DEM and thus capture small-scale characteristics. We are aware that this simplification cannot fully represent the actual characteristics of the floodplain. Studying small scale changes such as the shift of floodplain forest into Terra firme forest of few hundred metres would require a much finer resolution, but to roughly assess the possible changes in floodplain extend this approach is appropriate (see also Guimberteau et al., 2012). However, the estimated floodplain area and therewith the inundated patterns must be regarded as a first assessment at large spatial scales. Our large-scale approach may be applied to various 
river catchments where a digital elevation model is available. It is especially useful for large catchments where measured values are insufficiently available. Besides this, we can also reasonably reproduce floodable area with the approach of the modified TRMI. This is a basis to calculate actual inundated area, which enables us to estimate the extent of the area of strong interactions between land and river, as this land-river interface is of importance for plant and animal diversity.

\subsection{Future inundation patterns}

For the Amazon region, temperature is projected to increase by up to $3.5 \mathrm{~K}$ until the end of the century in the A2 scenario (Meehl et al., 2007). A decrease of precipitation is expected by the end of the century (especially during the southernhemisphere winter) in southern Amazonia, whereas an increase in precipitation is expected in the northern part (see e.g. Rammig et al., 2010). Precipitation is of course a direct driver for inundation patterns in the Amazon Basin and thus, the quality of precipitation projections is crucial for projecting future inundation patterns. It is well known that, until now, precipitation projections from General Circulation Models (GCMs) for the Amazon Basin are highly uncertain (e.g. Jupp et al., 2010), mainly due to model uncertainties in projecting land surface feedbacks, cloud formation and tropical Pacific and Atlantic sea surface temperature changes (e.g. Li et al., 2006). Rowell (2011) found highest uncertainties in the deep tropics, especially over South America. By applying the model results of 24 GCMs from the IPCC-AR4, we apply here the best available range of future precipitation and temperature projections, and we therefore also include the uncertainties in our results and discussions.

Our approach of slope dependent routing velocity successfully reproduces the hydrograph for the period 1961-1990 and we therefore compare this period to the projections for 2070-2099 to estimate changes in inundation patterns.

We identify several spatial and temporal shifts in the inundation regime under future climate conditions. For the western part of Amazonia 60-100\% of the models agree in displaying an increase in inundated area (Fig. 6a). For the eastern part there is no clear trend, about half of the models project an increase and half show a decrease in inundation area with proportions of 50-60\% and 40-60\%, respectively (Fig. 6b). Inundation tends to be lengthened by 2 to 3 months in the western basin, while in the east a shortening of the inundation duration is likely to occur on average by 0.5 to 1 months (Fig. 7). Furthermore our results indicate that in the north-west temporal shifts in the time of high and low water peak month will occur (Fig. 8). But the exact spatial and temporal dimensions of these changes remain unclear. We calculate a proportion of models in agreement of 40 to $50 \%$ (Fig. 8a) for a 3-months-forwards shift of the high water peak month in some parts of north-western Amazonia. There is a similar proportion for a 3-months-backwards shift in other parts of this region (Fig. 8b). A comparable pattern can be seen for the low water peak month (Fig. 8c and d).

The analysis of extreme years reveals that in a $30 \mathrm{yr}$ period the number of extremely dry years decreases by up to $3 \mathrm{yr}$ in north-west and south-east Amazonia (Fig. 9a). The proportion of models in agreement for 3 consecutive dry years decreases in most parts of Amazonia by 30 to $90 \%$, with an especially pronounced decrease in north-east and south-west Amazonia (Fig. 10a). Thus dry years are expected to occur less often and more discrete, leading to less predictable conditions. The analysis of extreme wet years shows changes in the number of -1.5 to $+1.5 \mathrm{yr}$ (Fig. $9 \mathrm{~b}$ ) in a $30 \mathrm{yr}$ period with no clear spatial pattern. The proportion for 3 consecutive years with extreme floods shows spatial differences. It decreases by up to $70 \%$ in the east, and it increases by up to $40 \%$ in the north-west (Fig. 10b). The extreme wet years persist longer in the west and are expected to occur more discrete in eastern Amazonia.

\section{Conclusions}

Under future conditions, modifications in flooded area and inundation duration as well as high and low water peak months and extreme years are likely to occur. Already in this decade, three years with extraordinary water amounts took place (Marengo et al., 2008, 2011; Nobre and De Simone Borma, 2009). The "Core Amazon" (Killeen and Solorzano, 2008) in the north-western part of the Amazon Basin experiences in our simulations most of these changes. An increase in inundated area, a lengthening of inundation duration, changes in low and high water peak month combined with shifts in occurrence and duration of extreme events have the potential to change this region substantially. The largescale changes in floodplain patterns found in this study may amplify projected climate and land-use change effects. We assume that the shifted flooding situation will influence several plant and animal species. This will lead to changes in species composition due to shifts in competition and food web networks. Since the biodiversity increases from east to west in the Amazon Basin (Worbes, 1997; ter Steege et al., 2003) the predicted changes in the north-western part will influence an area with a large and valuable species pool.

The projected changes in inundation have to potential for large-scale changes in water and carbon fluxes. The reduction of terrestrial evapotranspiration caused by an increase of inundated area and projected deforestation could lead to a reduced recycling of precipitation and further amplify drought conditions. The South American Low Level Jet is transporting atmospheric moisture from the Amazon southwards to the Parana-La Plata Basin (Marengo et al., 2009). A reduction of moisture in Amazonia might therefore reduce the precipitation of the entire region of South America. The outgassing $\mathrm{CO}_{2}$ from the Amazon Basin, which is currently estimated to be about $470 \mathrm{TgC}^{-1}$ (Richey et al., 2002), 
is likely to increase due to longer inundation in the west. The less pronounced shortening of inundation in the east might not be sufficiently able to balance the additional flux. Changes in regional climate will significantly change vegetation patterns in Amazonia and may cause additional carbon emissions. We conclude that changes in inundation patterns caused by climate change will significantly alter the highly complex system in the Amazon Basin.

\section{Supplementary material related to this article is available online at: http://www.hydrol-earth-syst-sci.net/ 17/2247/2013/hess-17-2247-2013-supplement.pdf.}

Acknowledgements. We thank "Pakt für Forschung der LeibnizGemeinschaft" for funding the TRACES project. We also thank John Lowry from Utah State University for providing AML script templates to calculate mTRMI and landform types. We thank Heike Zimmermann-Timm, Pia Parolin and Florian Wittmann for fruitful discussion. We also thank the anonymous reviewers for their helpful remarks. Finally we thank our LPJmL and Amazon Group colleagues at PIK.

Edited by: A. Bronstert

\section{References}

Alcamo, J., Henrichs, T., and Rösch, T.: World Water in 2025 Global modeling and scenario analysis for the World Commission on Water for the 21st Century. Report A0002, Center for Environmental Systems Research, University of Kassel, Kurt Wolters Strasse 3, 34109 Kassel, Germany, 2000.

Alsdorf, D. E., Rodríguez, E., and Lettenmaier, D. P.: Measuring surface water from space, Rev. Geophys., 45, RG2002, doi:10.1029/2006RG000197, 2007.

Alsdorf, D., Han, S.-C., Bates, P., and Melack, J.: Seasonal water storage on the Amazon floodplain measured from satellites, Remote Sens. Environ., 114, 2448-2456, doi:10.1016/j.rse.2010.05.020, 2010.

Anderson, L. O., Malhi, Y., Ladle, R. J., Aragão, L. E. O. C., Shimabukuro, Y., Phillips, O. L., Baker, T., Costa, A. C. L., Espejo, J. S., Higuchi, N., Laurance, W. F., López-González, G., Monteagudo, A., Núñez-Vargas, P., Peacock, J., Quesada, C. A., and Almeida, S.: Influence of landscape heterogeneity on spatial patterns of wood productivity, wood specific density and above ground biomass in Amazonia, Biogeosciences, 6, 1883-1902, doi:10.5194/bg-6-1883-2009, 2009.

Arnold, J. G. and Fohrer, N.: SWAT2000: current capabilities and research opportunities in applied watershed modelling, Hydrol. Process., 19, 563-572, doi:10.1002/hyp.5611, 2005.

Arora, V. K. and Boer, G. J.: Effects of simulated climate change on the hydrology of major river basins, J. Geophys. Res.-Atmos., 106, 3335-3348, 2001.

Bates, P. D.: Integrating remote sensing data with flood inundation models: how far have we got?, Hydrol. Process., 26, 2515-2521, doi:10.1002/hyp.9374, 2012.
Bates, P. and De Roo, A. P.: A simple raster-based model for flood inundation simulation, J. Hydrol., 236, 54-77, doi:10.1016/S0022-1694(00)00278-X, 2000.

Betts, R. A., Malhi, Y., and Roberts, J. T.: The future of the Amazon: new perspectives from climate, ecosystem and social sciences, Philos. T. R. Soc. B., 363, 1729-1735, doi:10.1098/rstb.2008.0011, 2008.

Biemans, H., Hutjes, R. W. A., Kabat, P., Strengers, B. J., Gerten, D., and Rost, S.: Effects of precipitation uncertainty on discharge calculations for main river basins, J. Hydrometeorol., 10, 10111025, doi:10.1175/2008jhm1067.1, 2009.

Biemans, H., Haddeland, I., Kabat, P., Ludwig, F., Hutjes, R. W. A., Heinke, J., Von Bloh, W., and Gerten, D.: Impact of reservoirs on river discharge and irrigation water supply during the 20th century, Water Resour. Res., 47, W03509, doi:10.1029/2009WR008929, 2011.

Birkett, C. M., Mertes, L. A. K., Dunne, T., Costa, M. H., and Jasinski, M. J.: Surface water dynamics in the Amazon Basin: Application of satellite radar altimetry, J. Geophys. Res.-Atmos., 107, 26/1-26/21, doi:10.1029/2001JD000609, 2002.

Bondeau, A., Smith, P. C., Zaehle, S., Schaphoff, S., Lucht, W., Cramer, W., Gerten, D., Lotze-Campen, H., Müller, C., Reichstein, M., and Smith, B.: Modelling the role of agriculture for the 20th century global terrestrial carbon balance, Global Change Biol., 13, 679-706, doi:10.1111/j.13652486.2006.01305.x, 2007.

Burrough, P. A.: Digital elevation models, in: Principles of geographical information systems for land resources assessment, edited by: Burrough, P. A., 39-55, Oxford University Press, New York, 1986.

Center for sustainability and the global environment (SAGE): River Discharge Database, available at: http://www.sage.wisc edu/riverdata (last access: 12 October 2007), 2007.

Coe, M. T., Costa, M. H., Botta, A., and Birkett, C.: Long-term simulations of discharge and floods in the Amazon Basin, J. Geophys. Res.-Atmos., 107, 8044, doi:10.1029/2001JD000740, 2002.

Cox, P. M., Betts, R. A., Collins, M., Harris, P. P., Huntingford, C., and Jones, C. D.: Amazonian forest dieback under climatecarbon cycle projections for the 21st century, Theor. Appl. Climatol., 78, 137-156, doi:10.1007/s00704-004-0049-4, 2004.

Döll, P. and Zhang, J.: Impact of climate change on freshwater ecosystems: a global-scale analysis of ecologically relevant river flow alterations, Hydrol. Earth Syst. Sci., 14, 783-799, doi:10.5194/hess-14-783-2010, 2010.

Döll, P., Kaspar, F., and Lehner, B.: A global hydrological model for deriving water availability indicators: model tuning and validation, J. Hydrol., 270, 105-134, 2003.

Donnegan, J. A., Butler, S. L., Kuegler, O., Stroud, B. J., Hiserote, B. A., and Rengulbai, K.: Palau's forest resources, 2003, in Resour. Bull. PNW-RB-252, 1-52, US Department of Agriculture, Forest Service, Pacific Northwest Research Station, Portland, OR, 2007.

FAO: The digitized soil map of the world (Release 1.0), Food and Agriculture Organization of the United Nations, Rome, Italy, 1991.

Fearnside, P. M.: Are climate change impacts already affecting tropical forest biomass?, Global Environ. Chang., 14, 299-302, doi:10.1016/j.gloenvcha.2004.02.001, 2004. 
Fekete, B. M., Vörösmarty, C. J., and Grabs, W.: Global composite runoff fields of observed river discharge and simulated water balances, Global Runoff Data Center, Koblenz, available at: http://www.bafg.de/nn_298486/GRDC/EN/02__Services/ 04__Report__Series/report__22,templateId=raw, property= publicationFile.pdf/report_22.pdf, 1999.

Foley, J. A., Botta, A., Coe, M. T., and Costa, M. H.: El Niño-Southern Oscillation and the climate, ecosystems and rivers of Amazonia, Global Biogeochem. Cy., 16, 79/1-79/17, doi:10.1029/2002GB001872, 2002.

Foley, J. A., Asner, G. P., Costa, M. H., Coe, M. T., DeFries, R., Gibbs, H. K., Howard, E. A., Olson, S., Patz, J., Ramankutty, N., and Snyder, P.: Amazonia revealed: forest degradation and loss of ecosystem goods and services in the Amazon Basin, Front. Ecol. Environ., 5, 25-32, doi:10.1890/15409295(2007)5[25:ARFDAL]2.0.CO;2, 2007.

Gaillardet, J., Dupré, B., Allègre, C. J., and Négrel, P.: Chemical and physical denudation in the Amazon River basin, Chem. Geol., 142, 141-173, 1997.

Gerten, D., Schaphoff, S., Haberlandt, U., Lucht, W., and Sitch, S.: Terrestrial vegetation and water balance - hydrological evaluation of a dynamic global vegetation model, J. Hydrol., 286, 249270, doi:10.1016/j.jhydrol.2003.09.029, 2004.

Gerten, D., Rost, S., Von Bloh, W., and Lucht, W.: Causes of change in 20th century global river discharge, Geophys. Res. Lett., 35, L20405, doi:10.1029/2008g1035258, 2008.

Gerten, D., Schaphoff, S., Rastgooy, J., Deryng, D., Wallace, C., Warren, R., and Edwards, N.: Quantification of Crop and Water Impacts under Scenarios from D5.1. ERMITAGE project report, Open University, Milton Keynes, UK, available at: http: //ermitage.cs.man.ac.uk/sites/default/files/D5.2.pdf, 2012.

Gordon, W. S., Famiglietti, J. S., Fowler, N. L., Kittel, T. G. F., and Hibbard, K. A.: Validation of simulated runoff from six terrestrial ecosystem models: results from VEMAP, Ecol. Appl., 14, 527545, doi:10.1890/02-5287, 2004.

Guimberteau, M., Drapeau, G., Ronchail, J., Sultan, B., Polcher, J., Martinez, J.-M., Prigent, C., Guyot, J.-L., Cochonneau, G., Espinoza, J. C., Filizola, N., Fraizy, P., Lavado, W., De Oliveira, E., Pombosa, R., Noriega, L., and Vauchel, P.: Discharge simulation in the sub-basins of the Amazon using ORCHIDEE forced by new datasets, Hydrol. Earth Syst. Sci., 16, 911-935, doi:10.5194/hess-16-911-2012, 2012.

Hamilton, S. K., Sippel, S. J., and Melack, J. M.: Comparison of inundation patterns among major South American floodplains, J. Geophys. Res.-Atmos., 107, 5/1-5/14, doi:10.1029/2000JD000306, 2002.

Hess, L. L., Melack, J. M., Novo, E., Barbosa, C. C. F., and Gastil, M.: Dual-season mapping of wetland inundation and vegetation for the central Amazon basin, Remote Sens. Environ., 87, 404428, 2003.

IPCC: Summary for policy makers, in: Climate change 2007: The physical science basis. Contribution of working group I to the fourth assessment report of the Intergovernmental Panel on Climate Change, edited by: Solomon, S., Qin, D., Manning, M., Chen, Z., Marquis, M., Averyt, K. B., Tignor, M., and Miller, H. L., Cambrigde University Press, Cambrigde, UK and New York, NY, USA, available at: http://www.ipcc.ch/publications_ and_data/ar4/wg1/en/contents.html, 2007.
Jachner, S., Van den Boogaart, K. G., and Petzoldt, T.: Statistical methods for the qualitative assessment of dynamic models with time delay (R package qualV), J. Stat. Softw., 22, 1-30, 2007.

Junk, W. J.: The Amazon floodplain - A sink or source for organic carbon?, Mitteilungen des Geologisch-Paläontologischen Instituts der Universität Hamburg, 58, 267-283, 1985.

Junk, W. J. and Piedade, M. T. F.: Plant life in the floodplain with special reference to herbaceous plants, in: The Central Amazon Floodplain, edited by: Junk, W. J., 147-185, Springer, Berlin, Germany, 1997.

Jupp, T. E., Cox, P. M., Rammig, A., Thonicke, K., Lucht, W., and Cramer, W.: Development of probability density functions for future South American rainfall, New Phytol., 187, 682-693, doi:10.1111/j.1469-8137.2010.03368.x, 2010.

Keddy, P. A., Fraser, L. H., Solomeshch, A. I., Junk, W. J., Campbell, D. R., Arroyo, M. T. K., and Alho, C. J. R.: Wet and wonderful: The world's largest wetlands are conservation priorities, Bioscience, 59, 39-51, doi:10.1525/bio.2009.59.1.8, 2009.

Killeen, T. J. and Solorzano, L. A.: Conservation strategies to mitigate impacts from climate change in Amazonia, Philos. T. R. Soc. B, 363, 1881-1888, doi:10.1098/rstb.2007.0018, 2008.

Langerwisch, F., Rost, S., Poulter, B., Zimmermann-Timm, H., and Cramer, W.: Assessing carbon dynamics in Amazonia with the dynamic global vegetation model LPJmL - discharge evaluation, Verh. Internat. Verein. Limnol., 30, 455-458, 2008.

Lehner, B. and Döll, P.: Development and validation of a global database of lakes, reservoirs and wetlands, J. Hydrol., 296, 1-22, doi:10.1016/j.jhydrol.2004.03.028, 2004.

Lenton, T. M., Held, H., Kriegler, E., Hall, J. W., Lucht, W., Rahmstorf, S., and Schellnhuber, H. J.: Tipping elements in the Earth's climate system, Proc. Natl. Acad. Sci., 105, 1786-1793, doi:10.1073/pnas.0705414105, 2008.

Li, W. H., Fu, R., and Dickinson, R. E.: Rainfall and its seasonality over the Amazon in the 21st century as assessed by the coupled models for the IPCC AR4, J. Geophys. Res.-Atmos., 111, 1-14, doi:10.1029/2005JD006355, 2006.

Liang, X. and Xie, Z.: A new surface runoff parameterization with subgrid-scale soil heterogeneity for land surface models, Adv. Water Resour., 24, 1173-1193, doi:10.1016/S03091708(01)00032-X, 2001.

Liang, X., Lettenmaier, D. P., Wood, E. F., and Burges, S. J.: A simple hydrologically based model of land surface water and energy fluxes for general circulation models, J. Geophys. Res., 99, 14415-14428, doi:10.1029/94JD00483, 1994.

Malhi, Y. and Wright, J.: Spatial patterns and recent trends in the climate of tropical rainforest regions, Philos. T. R. Soc. B, 359, 311-329, doi:10.1098/rstb.2003.1433, 2004.

Malhi, Y., Roberts, J. T., Betts, R. A., Killeen, T. J., Li, W., and Nobre, C. A.: Climate change, deforestation, and the fate of the Amazon, Science, 319, 169-172, 2008.

Marengo, J. A., Nobre, C. A., Tomasella, J., Cardoso, M. F., and Oyama, M. D.: Hydro-climatic and ecological behaviour of the drought of Amazonia in 2005, Philos. T. R. Soc. B, 363, 17731778, doi:10.1098/rstb.2007.0015, 2008.

Marengo, J., Nobre, C. A., Betts, R. A., Cox, P. M., Sampaio, G., and Salazar, L.: Global warming and climate change in Amazonia: Climate-vegetation feedback and impacts on water resources, in: Amazonia and Global Change, edited by: Keller, M., Bustamante, M., Gash, J., and Silva Dias, P., 273-292, American 
Geophysical Union, Washington, 2009.

Marengo, J. A., Tomasella, J., Alves, L. M., and Soares, W. R.: The drought of 2010 in the context of historical droughts in the Amazon region, Geophys. Res. Lett., 38, L12703, doi:10.1029/2011GL047436, 2011.

Mayer, D. G. and Butler, D. G.: Statistical validation, Ecol. Modell., 68, 21-32, doi:10.1016/0304-3800(93)90105-2, 1993.

Meehl, G. A., Stocker, T. F., Collins, W. D., Friedlingstein, P., Gaye, A. T., Gregory, J. M., Kitoh, A., Knutti, R., Murphy, J. M., Noda, A., Raper, S. C. B., Watterson, I. G., Weaver, A. J., and Zhao, Z.-C.: Global climate projections, in: Climate Change 2007: The Physical Science Basis. Contribution of Working Group I to the Fourth Assessment Report of the Intergovernmental Panel on Climate Change, edited by: Solomon, S., Qin, D., Manning, M., Chen, Z., Marquis, M., Averyt, K. B., Tignor, M., and Miller, H. L., Cambridge University Press, Cambrigde, UK and New York, NY, USA, 2007.

Melack, J. M., Hess, L. L., Gastil, M., Forsberg, B. R., Hamilton, S. K., Lima, I. B. T., and Novo, E. M. L.: Regionalization of methane emissions in the Amazon Basin with microwave remote sensing, Global Change Biol., 10, 530-544, doi:10.1111/j.15298817.2003.00763.x, 2004.

Mitchell, T. D. and Jones, P. D.: An improved method of constructing a database of monthly climate observations and associated high-resolution grids, Int. J. Climatol., 25, 693-712, doi:10.1002/joc.1181, 2005.

Moreira-Turcq, P., Seyler, P., Guyot, J. L., and Etcheber, H.: Exportation of organic carbon from the Amazon River and its main tributaries, Hydrol. Process., 17, 1329-1344, doi:10.1002/hyp.1287, 2003.

Naiman, R. J., Décamps, H., and McClain, M. E.: Riparia: Ecology, conservation, and management of streamside communities, Elsevier Academic Press ISBN-13:978-0126633153, 2005.

Nakićenović, N., Davidson, O., Davis, G., Grübler, A., Kram, T., Lebre La Rovere, E., Metz, B., Morita, T., Pepper, W., Pitcher, H., Sankovski, A., Shukla, P., Swart, R., Watson, R., and Dadi, Z.: IPCC Special report on emission scenarios, available at: http://www.ipcc.ch/ipccreports/sres/emission/index.php?idp= 0, 2000.

Nash, J. E. and Sutcliffe, J. V.: River flow forecasting through conceptual models part I - A discussion of principles, J. Hydrol., 10, 282-290, doi:10.1016/0022-1694(70)90255-6, 1970.

Nepstad, D. C., Tohver, I. M., Ray, D., Moutinho, P., and Cardinot, G.: Mortality of large trees and lianas following experimental drought in an Amazon forest, Ecology, 88, 2259-2269, doi:10.1890/06-1046.1, 2007.

Nobre, C. A. and De Simone Borma, L.: "Tipping points" for the Amazon forest, Current Opinion in Environmental Sustainability, 1, 28-36, doi:10.1016/j.cosust.2009.07.003, 2009.

Österle, H., Gerstengarbe, F. W., and Werner, P. C.: Homogenisierung und Aktualisierung des Klimadatensatzes des Climate Research Unit der Universitaet of East Anglia, Norwich. 6. Deutsche Klimatagung 2003 Potsdam, Germany, Terra Nostra, 2003, 326-329, 2003.

Parker, A. J.: The Topographic Relative Moisture Index: An approach to soil-moisture assessment in mountain terrain, Phys. Geogr., 3, 160-168, 1982.

Parolin, P., De Simone, O., Haase, K., Waldhoff, D., Rottenberger, S., Kuhn, U., Kesselmeier, J., Kleiss, B., Schmidt, W., Piedade,
M. T. F., and Junk, W. J.: Central Amazonian floodplain forests: Tree adaptations in a pulsing system, Bot. Rev., 70, 357-380, 2004.

Patt, H.: Hochwasser-Handbuch Auswirkungen und Schutz, Springer Verlag, Berlin, 2001.

Rammig, A., Jupp, T., Thonicke, K., Tietjen, B., Heinke, J., Ostberg, S., Lucht, W., Cramer, W., and Cox, P.: Estimating the risk of Amazonian forest dieback, New Phytolog., 187, 694-706, doi:10.1111/j.1469-8137.2010.03318.x, 2010.

Randall, D. A., Wood, R. A., Bony, S., Colman, R., Fichefet, T., Fyfe, J., Kattsov, V., Pitman, A., Shukla, J., Srinivasan, J., Stouffer, R. J., Sumi, A., and Taylor, K. E.: Climate models and their evaluation, in: Climate Change 2007: The Physical Science Basis. Contribution of Working Group I to the Fourth Assessment Report of the Intergovernmental Panel on Climate Change, edited by: Solomon, S., Qin, D., Manning, M., Chen, Z., Marquis, M., Averyt, K. B., Tignor, M., and Miller, H. L., Cambridge University Press, 2007.

Richey, J. E., Mertes, L. A. K., Dunne, T., Victoria, R. L., Forsberg, B. R., Tancredi, A. C. N. S., and Oliveira, E.: Sources and routing of the Amazon River flood wave, Global Biogeochem. Cy., 3, 191-204, 1989.

Richey, J. E., Melack, J. M., Aufdenkampe, A. K., Ballester, V. M., and Hess, L. L.: Outgassing from Amazonian rivers and wetlands as a large tropical source of atmospheric $\mathrm{CO}_{2}$, Nature, 416, 617620, doi:10.1038/416617a, 2002.

Rost, S., Gerten, D., Bondeau, A., Lucht, W., Rohwer, J., and Schaphoff, S.: Agricultural green and blue water consumption and its influence on the global water system, Water Resour. Res., 44, W09405, doi:10.1029/2007wr006331, 2008.

Rowell, D. P.: Sources of uncertainty in future changes in local precipitation, Clim. Dynam., 39, 1929-1950, doi:10.1007/s00382011-1210-2, 2011.

Seneviratne, S. I., Nicholls, N., Easterling, D., Goodess, C. M., Kanae, S., Kossin, J., Luo, Y., Marengo, J., McInnes, K., Rahimi, M., Reichstein, M., Sorteberg, A., Vera, C., and Zhang, X.: Changes in climate extremes and their impacts on the natural physical environment, in: Managing the Risks of Extreme Events and Disasters to Advance Climate Change Adaptation; A Special Report of Working Groups I and II of the Intergovernmental Panel on Climate Change, edited by: Field, C. B., Barros, V., Stocker, T. F., Qin, D., Dokken, D. J., Ebi, K. L., Mastrandrea, M. D., Mach, K. J., Plattner, G.-K., Allen, S. K., Tignor, M., and Midgley, P. M., 109-230, Cambrigde University Press, Cambrigde, UK and New York, NY, USA, 2012.

Sitch, S., Smith, B., Prentice, I. C., Arneth, A., Bondeau, A., Cramer, W., Kaplan, J. O., Levis, S., Lucht, W., Sykes, M. T., Thonicke, K., and Venevsky, S.: Evaluation of ecosystem dynamics, plant geography and terrestrial carbon cycling in the LPJ dynamic global vegetation model, Global Change Biol., 9, 161185, doi:10.1046/j.1365-2486.2003.00569.x, 2003.

Sitch, S., Huntingford, C., Gedney, N., Levy, P. E., Lomas, M., Piao, S. L., Betts, R., Ciais, P., Cox, P., Friedlingstein, P., Jones, C. D., Prentice, I. C., and Woodward, F. I.: Evaluation of the terrestrial carbon cycle, future plant geography and climate-carbon cycle feedbacks using five Dynamic Global Vegetation Models (DGVMs), Global Change Biol., 14, 2015-2039, doi:10.1111/j.1365-2486.2008.01626.x, 2008. 
ter Steege, H., Pitman, N., Sabatier, D., Castellanos, H., Van der Hout, P., Daly, D. C., Silveira, M., Phillips, O., Vasquez, R., Van Andel, T., Duivenvoorden, J., De Oliveira, A. A., Ek, R., Lilwah, R., Thomas, R., Van Essen, J., Baider, C., Maas, P., Mori, S., Terborgh, J., Núñez Vargas, P., Mogollón, H., and Morawetz, W.: A spatial model of tree alpha-diversity and tree density for the Amazon, Biodivers. Conserv., 12, 2255-2277, doi:10.1023/A:1024593414624, 2003.

Vigerstol, K. L. and Aukema, J. E.: A comparison of tools for modeling freshwater ecosystem services, J. Environ. Manage., 92, 2403-2409, doi:10.1016/j.jenvman.2011.06.040, 2011.

Wagner, W., Scipal, K., Pathe, C., Gerten, D., Lucht, W., and Rudolf, B.: Evaluation of the agreement between the first global remotely sensed soil moisture data with model and precipitation data, J. Geophys. Res., 108, 4611, doi:10.1029/2003JD003663, 2003.
Willmott, C. J.: Some comments on the evaluation of model performance, B. Am. Meteorol. Soc., 63, 1309-1313, 1982.

Wilson, M., Bates, P., Alsdorf, D., Forsberg, B., Horritt, M., Melack, J., Frappart, F., and Famiglietti, J.: Modeling large-scale inundation of Amazonian seasonally flooded wetlands, Geophys. Res. Lett., 34, L15404, doi:10.1029/2007GL030156, 2007.

Worbes, M.: The forest ecosystem of the floodplains, in: The Central Amazon Floodplain, edited by: Junk, W. J., 223-265, Springer, Berlin, Germany, 1997.

WWF HydroSHEDS: HydroSHEDS, available at: http: //hydrosheds.cr.usgs.gov/ (last access: 15 October 2007), 2007. 